\title{
THE LIQUIDITY-PROFITABILITY TRADE-OFF IN BULGARIA IN TERMS OF THE CHANGED FINANCIAL MANAGEMENT FUNCTIONS DURING CRISIS
}

\author{
Evgeni Raykov*
}

Received: 16. 1. 2017

Preliminary communication

Accepted: 17. 4. 2017

UDC 005.915:338.124.4(497.2)

The analysis evaluates the basic functions of modern financial managers and important aspects related to their roles in the business environment. In consideration of the global changes within the economic and financial system after 2007, the role of financial managers in corporations significantly changed. This has happened with the increasing number of functions they perform and with extending the influence of the financial manager on almost all other areas of activity within companies - trading, logistics, property management, production and technology through changing highlights and guidance on financial policies, changes in the scope of activities and time determination of the decisions taken. The analysis points at the increasing role of liquidity management in times of crisis and its effect on maximizing company's results. The effective financial performance should guarantee a minimum impact of liquidity decisions on profitability and wealth. Empirical tests for the Bulgarian economy in crisis showed weak but clearly negative relationship between controllable liquidity and operational profitability in long term. Moreover, the volatility of liquidity remains relatively low and poorly related to the considerable variations in profitability. Contrary to that, the liquidity is not significantly influenced by the capital gains due to the instable profitability for the analysed period.

Keywords: Functions of the financial management, Financial and economic crisis, New role of financial managers, Liquidity and profitability trade-off

\footnotetext{
* Evgeni Raykov, PhD, Chief Assistant Professor, Finance and Accountancy Faculty, Finance Department, University of National and World Economy, Office 2026 , "8 dekemvri" street, 1700 Sofia, Bulgaria, E-mail: evgeni_raikov@abv.bg
} 
Management, Vol. 22, 2017, 1, pp. 135-156

E. Raykov: The liquidity-profitability trade-off in Bulgaria in terms of the changed financial...

\section{INTRODUCTION}

The primary objective of financial managers is commonly defined through their role in maximizing the wealth of shareholders in the long term. The complexity of this objective determines the conflicting relationship of the financial manager with all other functional centres in the company, even the owners. Within the framework of the financial crisis from 2007 onwards, the role of the financial professionals has become more complex. Once the moral hazard and ethics of financial industry boosted the credit bubble, sharp curtail led to economic downturns. On the other hand, financial management appeared to solve internal imbalances arising from bad financial decisions and unrealistic sales objectives on a macroeconomic level. Financial management was relying more on flexibility instead on controllable decision-making process. The changes reflect the growing impact of globalization process in the World and the leading role of technology. Thus, faster pace of business required integrated financial management through redistribution of responsibilities. In times of crisis, financial management gains ground because it affects the stability of the company's liquidity and solvency, and ultimately the existence and preservation of owners' capital. There is a clear commitment of financial managers with wider range of issues and this increases the legal burden of regulations, control and bureaucratic costs for the company.

Crisis management places high importance on liquidity due to the lack of access to capital or higher cost of financing. In times of economic growth and stability, the excessive access to low cost capital sources facilitates the matching of cash inflows and outflows. Liquidity requires withdrawal of profitable funds for the need of liquidity balance to ensure stability. On the other hand, the liquidity might be easily secured by higher rates of profitability and substantial increase in invested working capital. Liquidity has always been a specific priority area for financial managers. The difficulty of managing liquidity is strengthened by the need to compensate all detracted sources from the operating cycle and the likely reduction of turnover and profitability. Liquidity-related risks can often lead to deterioration of the financial situation and even bankruptcy. Under the circumstances of the recent crisis after 2007, with falling sales and clients' failure, the financial management is entrusted with minimizing the impact of higher liquidity requirements on profitability potential of the business. The main objective of this study is to specify appropriate measures in terms of the liquidity-profitability trade-off to assess the changed financial management scope of impact under crisis environment. In view of that, the following three hypotheses will be verified and considered: 
Management, Vol. 20, 2017, 1, pp. 135-156

E. Raykov: The liquidity-profitability trade-off in Bulgaria in terms of the changed financial...

H1: The relationship between liquidity and profitability for the selected Bulgarian companies during the recent financial and economy crisis is negative in the long run.

H2: The liquidity influences profitability but not vice versa.

H3: In terms of the recent financial and economic crisis, the financial managers in Bulgaria did not trade off liquidity for profitability.

\section{LITERATURE OVERVIEW}

Paul Krugman (2010) and Argandona (2012) qualified the recent financial and economic crisis as a combination of "moralism and complacency" and "ethical issues", leading to a failure in the patterns of leadership and management and collapse of the existing economic and social model. Salhman (2009) qualified the crisis in the following way: "The macroeconomic problems were the result of bad microeconomic decisions". Pereira (2010) and Azkunaga et al (2013) analysed the process of "financialization" and creating massive artificial financial wealth through deregulation of existing financial operations and reducing control in order to maximize and expand the potential risks for investors. The transformation of financial management into a leading concept for economic and corporate governance is a trend that undoubtedly affected the potential for economic growth and development of companies.

According to CIMA Global Report Survey (2011), more than 30\% of the global senior and financial managers expect an increase in staff engaged in financial activities because of the crisis and $84 \%$ do not foresee any dismissals concerning financial personnel. Ernst \& Young (2008) and Blackwell publishing (1998) discuss the increasing role of financial management at the beginning of the crisis concerning also the personal expert skills, training, talent and quality of provided information. These requirements are expanded to the ability to quickly generate financial reports with high analytical and informational value to senior management in order to maximize profits in a response to technological developments in the real sector (Qfinance, 2008). Ramagopal (2008) noted that modern financial management is revolutionizing from recruitment sources for financing to the pursuit of effective utilization of available resources that moves the focus from optimizing capital structure and the cost of liabilities to performance management of assets.

In a later research of Ernst \& Young (2011), the financial manager is considered responsible for identifying and pursuing the strategic objectives of 
the company, crisis liquidity management, accountability, cost reduction and risk hedging, commitment to issues of trade policy, information technology, property management, mergers and acquisitions, and emerging markets. One of the most important highlights is undoubtedly on maintaining direct control over cash flows. Dimitrescu et al. (2008) indicate that the financial manager should carry out continuous monitoring of processes in the economy and signs of deepening financial crisis. The authors also point out that financial managers should maximize the liquidity, restructure debts, minimize operational risk, promote active use of hedging instruments for risk management and prepare for crisis scenarios. Liquidity management, in particular, is expected to overcome the late payments from customers and the lack of free cash flows from the financial system to the real sector and business. The increasing importance of liquidity management in crisis is similarly outlined by Eljelly (2004), Ware (2015), Lamberg et al (2009), Demirhan et al (2014), Owolabi et al (2012).

The impact of liquidity on corporations' financial results has always been widely discussed with the aim of proving or rejecting the ability of the cash flow management to add value to the business. A basic study of Shin et al (1998) revealed that investigating the net trade cycle and profitability (in terms of operating income plus depreciation) for nearly 60.000 companies, and in a long-term period 1975-1994, shows a strong negative association between the two variables thus creating shareholder's value through reasonable reduction in liquidity. Significant influence is found by Maqsood (2016) and Ahmad (2016), but depending on the used indicators the relation varies from negative to positive. Wilson (2004) confirmed these results for emerging markets and Irawan et al (2015) and Batra et al (2016) found negative, but also insignificant, relationship between liquidity and profitability in Indonesia and India. Negative relationship is also observed by Deloof (2003), Afza et al (2007), Samilogu et al (2008), Saluja et al (2012), Priya et al (2013) and Ehiedu (2014).

Weak or no relationship between working capital management and profitability is found by Niresh (2012), Cook (2012), Lamberg et al (2009), Husaria (2015), Ware (2015), Rudin et al (2016), Ben-Caleb et al (2016), Tamragundi (2016). At the same time many sources like Mandal et al (2010), Vieira (2010), Mihajlov (2014), Mushtaq et al (2015), Kung'u (2017) propose the idea of positive influence of liquidity on profitability. A particular field within the published literature refers to liquidity mainly as a mean of assuring smooth running of the business rather than as an instrument for better performance and major influence of companies' operations - Valrshney (2008), Bardia (2007), Lamberg et al (2009). 
As far as the choice of the analysed variables is concerned, the ratio of return on current assets (ROCA) is relatively a new one to be considered in the study of liquidity-profitability trade-off. Furthermore, it has been recommended by Gayathri (2015), Croal (2003), Okay et al (2015), Siegel et al (2000), Burja (2011), Batrancea (2013), Bolek (2014), Bunget et al (2015), Szoka (2015). Still Levin et al (1987) to analyse ROCA instead of ROA and ROE as being deformed by shareholders' decisions to lease company's assets. The liquidity indicator varies from study to study referring to working capital sufficiency, cash conversion cycle, and current or acid-test liquidity ratio. The quick ratio behaviour and impact on profitability was investigated by Untwal (2011), Ahmad (2016), Irawan, et al (2015), Lamberg et al (2009), Khidmat (2014), AliKhan et al (2016), Kung'u (2017).

\section{DATA AND METHODOLOGY}

The analysis of liquidity and the effects on profitability uses data from quarterly financial reports of 20 selected companies from different sectors of the Bulgarian economy included in the BGBX40 index of the Bulgarian Stock Exchange for the period 2007-2015. The survey covered 20 companies constantly participating in the calculation of BGBX40 (BG40 to March 2014) for most of the analysed period. All selected companies have also had the highest number of transactions and the highest median value of daily turnover during the last six months.

Liquidity and profitability indicators are calculated based on the collected data for each company. Liquidity is measured by the Quick ratio (cash plus receivables divided by current liabilities) and profitability is measured by the Return on Current Assets - ROCA (Earnings before interest and taxes divided by the Current assets). The quick ratio is basically the most eligible indicator of the controllable current assets availability that stays within the functionality range of the contemporary financial management. It allows consideration of the ability to regulate liquidity through the level and structure of the short-term liabilities and cash flow dynamics. The widely used indicators like cash conversion cycle (CCC) or current ratio (CR) generalize too many functional impacts like logistics, sales or production decisions that somehow dilute the specific but complex role of the contemporary financial management. The increasing matter of financial management is now more focused on asset management instead of long-term liabilities and the objective possibility of control is applicable basically to cash and receivables' availability (measured by the quick ratio). These two provide the necessary backup for current liabilities revealing the priorities of the operational financial management during crisis 
Management, Vol. 22, 2017, 1, pp. 135-156

E. Raykov: The liquidity-profitability trade-off in Bulgaria in terms of the changed financial...

and separating the influence of other functional centres within the company. ROCA also stresses the operational aspects of profitability and working capital management as a means of liquidity guarantee. It represents a proper measure for direct allocation of the complicated working capital decisions detaching the influence of long-term investment activities and depreciation policies. The classic profitability ratios, Return on assets (ROA) or Return on Equity (ROE), do not cover the effects of the working capital management as they identify a more complex picture of the company's output. The analysis of the liquidity profitability relation for the period after the beginning of the crisis of 2007 is based on the average quarter Quick liquidity ratio and ROCA and the percentage change in their time values.

\section{THE MODERN FUNCTIONAL ASPECT OF FINANCIAL MANAGEMENT}

Table 1. Functional structure of the contemporary financial management

\begin{tabular}{|l|l|}
\hline \multicolumn{1}{|c|}{ Type of Function } & \multicolumn{1}{c|}{ Key aims } \\
\hline Cash Flow Management & $\begin{array}{l}\text { Balancing cash inflows and outflows according to } \\
\text { dynamically changing economic realities and liquidity. }\end{array}$ \\
\hline $\begin{array}{l}\text { Planning and financial } \\
\text { analysis }\end{array}$ & $\begin{array}{l}\text { Participation in defining strategic goals of the company, } \\
\text { performing in-depth analysis and providing quality } \\
\text { information base for decision-making, improve efficiency } \\
\text { and profitability of the business. }\end{array}$ \\
\hline $\begin{array}{l}\text { Managing relationships } \\
\text { with financial institutions }\end{array}$ & $\begin{array}{l}\text { Ensuring optimal capital structure and financing costs, } \\
\text { effectively hedging risk on the capital markets, working } \\
\text { capital financing.. }\end{array}$ \\
\hline $\begin{array}{l}\text { Managing financial } \\
\text { department and structure }\end{array}$ & $\begin{array}{l}\text { Internal control, calculations, reporting and compliance, } \\
\text { taxes, control. }\end{array}$ \\
\hline $\begin{array}{l}\text { Balance of interests of } \\
\text { various entities in the } \\
\text { structure of companies }\end{array}$ & $\begin{array}{l}\text { Placing the framework and creating conditions for } \\
\text { effective functioning of the organization. }\end{array}$ \\
\hline
\end{tabular}

Source: Author's research.

Managing cash flows is associated with the control over trade policy, monitoring and collection of receivables, as well as subsequent planning and daily adjustment of outgoing payments according to the company's capacity and liquidity needs. Cash inflows are never guaranteed but rather partially manageable through the determined framework. Being in full control of cash outflows allows financial managers to regulate liquidity and cash balance through the value of current liabilities - agreed on a contractual basis or spontaneous. Liquidity commitment, although traditional, is arising in crisis and 
Management, Vol. 20, 2017, 1, pp. 135-156

E. Raykov: The liquidity-profitability trade-off in Bulgaria in terms of the changed financial...

requires risk approach that will not allow a slowdown of the conversion cycle and respectively affect profitability rates.

Managing the financial department and planning business activities during crisis is associated with increasing reliability of information and controlling nature of the financial activities needed for sound management decision making. Relations with financial institutions are specific and require professional, long-term relationships that the financial manager should gradually develop. The list of such relations includes banks, investment firms, insurance companies, financial houses, credit agencies, auditors, and lawyers. Namely, the financial manager is expected to communicate with the banks regarding the necessary funding for the company, changes in interest rates and fees, securities accounts, exchange rate guarantees, and the balance of external and internal liquidity. This function has constantly been gaining in importance in terms of the limited access to financing and increased cost of capital after 2007. In addition, relations with investment intermediaries help manage the cash surplus in the short term and in case of issuing new shares or bonds or hedging some positions in the company. On the other hand, the insurance policy of the company is directly related to the effective property management.

The "balance of interests" of different functional parts of the company has the most significant place within the proposed classification. This function entails aiming all structural units and all related assets and liabilities, in order to achieve the main goals of the company in compliance with the relevant criteria for optimality. There has always been an imbalance between personal goals of employees and managers. Thus, the financial manager should define goals and track optimization criteria set by the proposed framework. These activities often put the financial manager in a conflicting position within the company. The instruments for implementing this function include cash flow management and liquidity influence for pressure towards optimization of current assets investment and related costs.

The crisis role of the financial manager can be summarized as follows: defining the extent to which each centre of influence in the company can affect the value of the company - this includes commercial terms for the sale on credit, optimal amounts of materials and production in stock, investing in new commercial projects, price level and calculation of commercial gain or loss, setting limits on the cost of components and functional areas, and, ultimately, optimizing cash balance and cash flow. 


\section{Management, Vol. 22, 2017, 1, pp. 135-156}

E. Raykov: The liquidity-profitability trade-off in Bulgaria in terms of the changed financial...

Based on the effects and the financial framework for each process, the financial manager should provide the necessary funding, in compliance with the timing of the used short-term and long-term resources and with the capital turnover at the lowest possible cost to assure the profit margin. The insufficient financing has to be regulated by active cash flow and liquidity management.

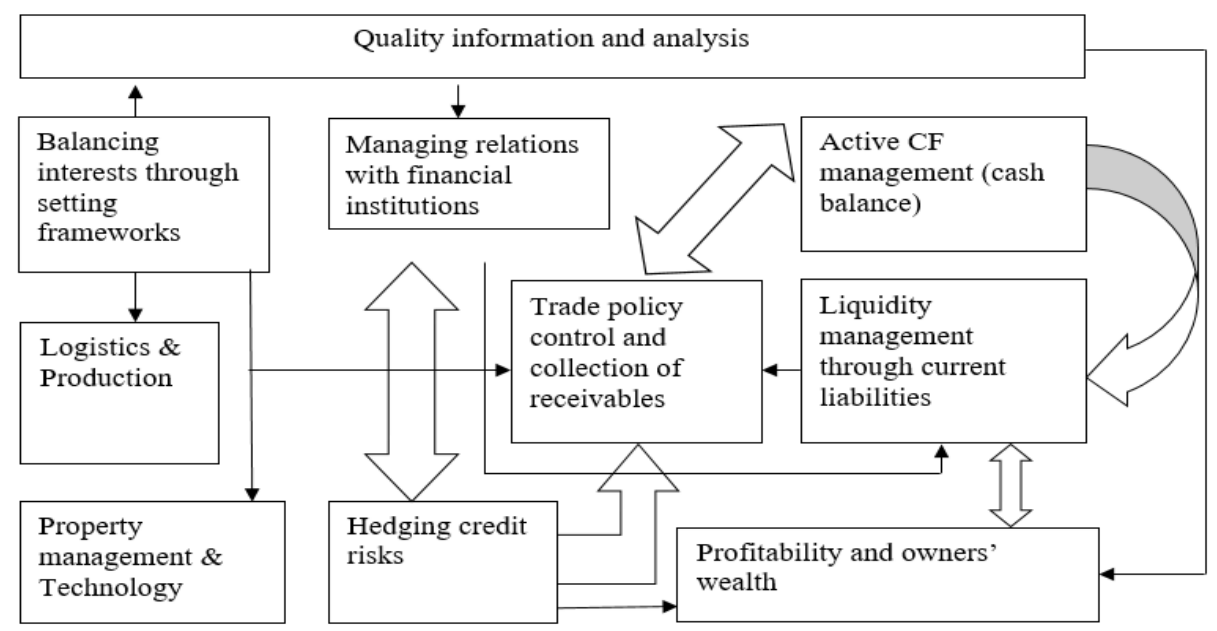

Figure 1. Interaction mechanisms of modern financial crisis management

Source: Author's research.

The essential characteristics and conclusions about financial management during crisis can be generalized as follows:

- Greed and ethics - the crisis of 2007 is a result of excessive pursuit of the main driving forces in the financial sector of the economy to generate higher profits without taking into account the extent of the risks and long-term stability of the economic system. This aspiration is closely related to ethics of bankers and investment firms.

- Moving from macro- to micro-contractions in business - apart from inadequate policies of monetary and fiscal authorities and banks, intermediaries and investors, the financial "bubble" quickly infected the real sector by establishing the same policies, concerning efficiency and risk at the micro level, with similar consequences. In addition to limiting business activity and resolving internal problems through restructuring or increased funding, crisis occurred mostly due to inadequate management of the risk - return relation. 
- Artificial business and real value added economic activities based on excessively "inflated" sector funding and weak collaterals were left with no credit support and followed by bankruptcies. Readjustment of employment, consumption, and structural changes will require considerable time to approach perfect competition. One aspect of the crisis is precisely the deformation of the markets by hyperactivity and the power of the financial institutions before 2007. This was combined with optimism, weak public regulation and high tolerance threshold among people and businesses.

- A healthy business suffers losses - the underlying economic activity which generally followed the rules and ethical norms, carried out internal control and effective risk management, also suffered losses because of the limited access to capital, modest investment opportunities, and increased cost of funding and poor sales.

\section{FINANCIAL MANAGEMENT AND THE CRISIS - THE LIQUIDITY FOCUS}

In terms of the lack of funding, a decrease in asset value and increase in resource prices, the role of financial manager is to identify internal reserves to offset the losses and transfer these inconsistencies out into the real economy. Unfortunately, this process often prevents additional value gains and reinforces the trend towards decline, restrictions, over-regulation and total downturn in growth. Financial managers usually reduce all costs to a minimum so that the system can still function as relatively stable. Financial decisions restrict trade policy, payment terms, inventories, investment activity, and property and asset sales. All these activities are solely aimed at maintaining the business. Managers are supposed to look inward to the business and look for reserves through more effective asset management, cost reductions and cash flow floating, including decisions on new investment projects, restrictions of current investments, and pressure on cutting costs, postpone outflows (payments), back up availability of inventory and production, receivables management and credit risk hedging. These emerging functional priorities have been clearly defined by the new operational nature of modern financial management and are directly related to the maintenance of liquidity. The success of financial policy in times of crisis requires additional resources involved and higher administrative burden to ensure that the main objectives of the business before the crisis can still be achieved.

The increasing role of the financial management during crisis is based on the presumption that the effect of avoiding erosion of wealth for entrepreneurs, 
Management, Vol. 22, 2017, 1, pp. 135-156

E. Raykov: The liquidity-profitability trade-off in Bulgaria in terms of the changed financial...

due to financial activities is greater than the potential yield, which investors would have normally made in times of economic growth, financial stability and better access to financing. Modern financial management offers the possibility of achieving this goal mainly through liquidity management. It stresses cash flows and regulation of cash balance, as well as the flexibility of short-term liabilities, supported by the scanty and non-flexible long-term financing options. The success of this financial management strategy in crisis might be revealed by implementing simultaneously active influence on the value, price and time structure of liabilities and controllable current assets. The goal is to provide liquidity balance and increase the wealth of shareholders, without affecting the internal sources for growth. The missing long-term capital or debt capital open space for the increased role of current liabilities. They are managed through active cash-flow regulation strategies, due to their short-term dynamics and specific risk profiles. This process is clearly supported by the transition from liabilities to asset-oriented approach and to the controllable or subject-tooptimization current assets. Thus, the working capital strengthened its position as an important factor for keeping the ongoing activities of the companies in tough times.

Recognizing liquidity as the main focus of the financial management policies during the recent crisis poses the question of its influence on the company performance. The nature of liquidity management is strictly financial, presuming a certain level of working capital invested in highly liquid assets like cash and securities. These sources are stirred away from the operations' cycle, causing an obvious aggravation of turnover and directly damaging profitability. The negative correlation between liquidity needs and potential sales and profits usually provokes a clash between strict financial responsibilities and objectives of other functional entities in the company. These conflicts further enhance the complexity of the process of maximizing shareholders' wealth and push up the contemporary financial management to spread into a vast functional range of activities and responsibilities.

The lack of reliable, long-term sources of capital in the last decade left financial managers with no other option, but to increase current assets availability and the share of highly liquid assets to guarantee the basic going concern principle. Following this direction, with highly unpredictable consumption and sales, can only boost the negative effects of the suffering growth. It can be also the cause of bankruptcy, because of financial losses instead of liquidity or solvency obstacles. Improving liquidity in crisis could be attained either through optimization of current assets and related costs associated with their use, or through extending and increasing the fixed long- 
Management, Vol. 20, 2017, 1, pp. 135-156

E. Raykov: The liquidity-profitability trade-off in Bulgaria in terms of the changed financial...

term share of current assets, seen as the minimum residual balance. The first option reflects the ability of the financial manager to get current assets under control. Controllable assets should include cash and securities (directly conducted) and accounts receivable (controlled indirectly through credit policies and receivables collection). All other crucial types of short-term assets like inventory, work-in-progress, and production depend on a wider combination of specific factors far out of the financial management, i.e. in the field of manufacturing, logistics, technology, entrepreneurship and sales. The impact on this process comes from the continuous pursuit of cost reduction performed by financial departments. The opportunity to realize a higher percentage of profitability calls for additional sources for maintaining better liquidity while bringing up the matter of likely existence of simultaneity causality (Hypothesis 2). The second option refers to the ability of the financial management to perform aggressive prolongation and increase the value of short-term liabilities shifting among all possible sources, investing efforts to stabilize the implicit cost of capital and avoid subversion of sales or business suspension.

Balancing these two options means to guarantee the acid-test or controllable liquidity. It consolidates the dynamics of the controllable current assets and current liabilities regulated by the cash flow management as a central concept of the financial management. Applying this functional approach on liquidity requires a stable equilibrium between the value of assets and liabilities and the structure that will result in weak or no relationship between liquidity and profitability in the long term (Hypothesis 1). In times of crisis, the higher liquidity risk aggravates the necessity of successful adaptation of this correlation through financial management policies and instruments. In practice, this means avoiding the liquidity-profitability trade-off in times of strong tension in order to increase the ability to meet the floating current obligations of the business without incurring substantial losses (Hypothesis 3). In case of significant correlation between both categories (inability of financial management to deal with this problem), building up reserves of liquidity (imposed by the crisis conditions) will likely sacrifice profitability and shareholders' wealth to a large extent.

The economy of Bulgaria entered the financial crisis slowly due to close alignment with the economy of the EU. The fall of GDP started in 2007 reaching its down of $-4.2 \%$ in 2009 and then stabilized at levels under the World average annual values (World Bank, 2016). Inflation fell substantially after 2009. The main characteristics of the corporate crisis environment included suspension of the further growth of bank loans (relatively stable for the 
period 2008-2013), 22 times increase in the value of bad loans, 30\% growth of intercompany debts and almost doubled related entities loans for the period 2007-2013, more than 5 times increase in the number of bankrupt companies which peaked in 2012 along with a major downfall in foreign direct investment (more than 10 times from 2007 to 2010), according to Bulgarian National Bank (2016).

In the field of working capital management, the main tendencies include constant decrease in the weighted average cost of working capital since 2009, following the initial boost in capital costs and the increase in current assets investment and liquidity. Although the share of working capital in sales was kept stable, increase in short-term sources of financing and related entities receivables boosted the use of retained earnings for short-term operational investments (Raykov, 2017).

In the environment of insufficient growth and detention of traditional capital sources, the role of internal reserves, liquidity and cash flow management increases substantially.

\section{EMPIRICAL RESULTS}

\subsection{Empirical test of the Hypothesis 1}

Long-term relationship between liquidity and profitability in the companies is considered using co-integration analysis normally used for detecting longterm relationship between integrated non-stationary variables of the same order, i.e. variables with trend, but which, after transformation of the input data (with use of their first differences, for example) are converted to stationary variables. Those modifying procedures, however, cause loss of information on the dynamics of the variables and underestimation of the relationship between them (Engle et al., 1987).

However, we examined the co-integration between two or more nonstationary variables, using the non-stationary data to find a relation between them. Therefore, before the co-integration analysis the average Quick Liquidity Ratio and ROCA are tested for stationary with Augmented Dickey-Fuller (ADF) Unit Root Test. 
Management, Vol. 20, 2017, 1, pp. 135-156

E. Raykov: The liquidity-profitability trade-off in Bulgaria in terms of the changed financial...

Table 2. Augmented Dickey-Fuller (ADF) unit root test

\begin{tabular}{|c|c|c|c|c|c|}
\hline \multirow[b]{2}{*}{ Hypothesis } & \multirow[b]{2}{*}{$\begin{array}{c}\text { Test } \\
\text { critical } \\
\text { values }\end{array}$} & \multicolumn{2}{|c|}{$\begin{array}{l}\text { Average Quick } \\
\text { Liquidity Ratio }\end{array}$} & \multicolumn{2}{|c|}{ Average ROCA } \\
\hline & & $\stackrel{t-}{\text { Statistic }}$ & Probability & $\begin{array}{c}\text { t- } \\
\text { Statistic }\end{array}$ & Probability \\
\hline $\begin{array}{l}\mathrm{H}_{0} \text { : The data is } \\
\text { stationary. }\end{array}$ & $\begin{array}{l}1 \% \text { level } \\
5 \% \text { level } \\
10 \% \text { level }\end{array}$ & $\begin{array}{l}\underline{0.5449} \\
-3.6537 \\
-2.9571 \\
-2.6174\end{array}$ & $\begin{array}{l}0.9857>0.05, \\
\text { the data is } \\
\text { non- } \\
\text { stationary. }\end{array}$ & $\begin{array}{l}-1.1462 \\
-3.6537 \\
-2.9571 \\
-2.6174\end{array}$ & $\begin{array}{l}0.6849>0.05, \\
\text { the data is } \\
\text { non- } \\
\text { stationary. }\end{array}$ \\
\hline $\begin{array}{l}\text { Ho: The first } \\
\text { differences are } \\
\text { stationary. }\end{array}$ & $\begin{array}{l}1 \% \text { level } \\
5 \% \text { level } \\
10 \% \text { level }\end{array}$ & $\begin{array}{l}-6.1005 \\
-3.6537 \\
-2.9571 \\
-2.6174\end{array}$ & $\begin{array}{l}0.0000<0.05, \\
\text { the first } \\
\text { differences } \\
\text { are stationary. }\end{array}$ & $\begin{array}{l}\frac{-11.5053}{-3.6537} \\
-2.9571 \\
-2.6174\end{array}$ & $\begin{array}{l}0.0000<0.05, \\
\text { the first } \\
\text { differences } \\
\text { are stationary. }\end{array}$ \\
\hline
\end{tabular}

Source: Research results.

With alpha risk (type I error) of 5\%, the ADF test results showed that the average Quick Liquidity Ratio and the average ROCA are non-stationary and integrated of the same order, i.e. the first differences of the output data are stationary. Based on this data analysis the co-integration analysis of the relationship liquidity-profitability during crisis is examined using econometric software Eviews and the Johansen co-integration test.

Table 3. Johansen co-integration test results

\begin{tabular}{|l|c|c|c|}
\hline $\begin{array}{c}\text { Hypothesized number of } \\
\text { cointegration equations }\end{array}$ & $\begin{array}{c}\text { Trace } \\
\text { Statistic }\end{array}$ & $\begin{array}{c}\text { Critical Value (5\% } \\
\text { risk) }\end{array}$ & Probability \\
\hline None (null hypothesis) & 31.08206 & 15.49471 & $0.0001<0.05$ \\
\hline $\begin{array}{l}\text { At most 1(null } \\
\text { hypothesis) }\end{array}$ & 0.0697 & 3.841466 & $0.7916>0.05$ \\
\hline
\end{tabular}

Source: Research results.

The Trace statistics verifies whether there is a long-term relationship between variables by calculating the equations between them. If there is a relationship, then the value of Trace statistics will be greater than the critical value and the probability will be less than the selected alpha risk (type I error) $5 \%$ (0.05). This means that at least one co-integration equation will exist at least. The null hypothesis of no long-term relationship will be rejected and the alternative hypothesis of a long-term relationship between the variables will be accepted. Since the probability (0.001) is lower than the alpha risk $(0.05$ or $5 \%)$, 
Management, Vol. 22, 2017, 1, pp. 135-156

E. Raykov: The liquidity-profitability trade-off in Bulgaria in terms of the changed financial...

the alternative hypothesis of a long-term relationship between the variables can be accepted.

The negative correlation between liquidity and profitability is confirmed by the Least Square Regression Analysis conducted in Eviews.

Table 4. Least square regression analysis results

\begin{tabular}{|l|c|l|c|c|}
\hline \multicolumn{1}{|c|}{ Variable } & Coefficient & Standard Error & t-Statistic & Probability \\
\hline C & 0.058424 & 0.020763 & 2.813825 & 0.0081 \\
\hline $\begin{array}{l}\text { Average Quick Liquidity } \\
\text { Ratio }\end{array}$ & -0.032935 & 0.013138 & -2.506968 & 0.0171 \\
\hline R-squared & 0.156011 & Akaike info criterion & -3.056963 \\
\hline Adjusted R-squared & 0.131188 & Schwarz criterion & -2.968990 \\
\hline Log likelihood & 57.02534 & F-statistic & 6.284886 \\
\hline Durbin-Watson stat & 2.739653 & Prob (F-statistic) & 0.017121 \\
\hline
\end{tabular}

Note: Dependent variable: Average Return on Current Assets (ROCA). Method: Least squares. Sample: 2007Q1-2015Q4.

Source: Research results.

The results of the regression analysis showed the negative relationship between the liquidity and profitability indicators as the sign of the average Quick Liquidity Ratio coefficient is negative. This has a minor influence on ROCA as Adjusted R-squared is only $13 \%$. It should be noted, however, that the implementation of regression analysis does not comply with one of the requirements of the analysis - the stationary input data. Since the ADF test showed that the data is non-stationary, the results of the analysis regarding the value of the coefficient of determination (Adjusted R-squared) and statistical significance of the regression coefficient (Average Quick Liquidity Ratio), cannot be considered completely correct. Although the negative sign in front of the regression coefficient remained, it is possible that the coefficient of determination and the statistical significance of regression coefficient was somewhat overstated. But this does not change the result of the negative relationship between liquidity and profitability.

\subsection{Empirical test of the Hypothesis 2}

The basis of causation analysis between liquidity and profitability is the long-term relationship between these two variables. The verification of the impact between the variables is determined by Granger causality test. Since the 
Management, Vol. 20, 2017, 1, pp. 135-156

E. Raykov: The liquidity-profitability trade-off in Bulgaria in terms of the changed financial...

test is usually based on stationary data, and the ADF test showed that the variables in this case are non-stationary, for applying the Granger causality and obtaining the correct results, testing in Eviews is determined through the TodaYamamoto procedure (Giles, 2011).

Table 5. Granger Causality Test Results

\begin{tabular}{|l|c|c|}
\hline \multicolumn{1}{|c|}{ Hypothesis } & Chi-sq Statistic & Probability \\
\hline The liquidity influenced profitability. & 12.13805 & $\mathbf{0 . 0 0 2 3}<\mathbf{0 . 0 5}$ \\
\hline The profitability influenced liquidity. & 1.973687 & $0.3728>0.05$ \\
\hline
\end{tabular}

Source: Research results

The Granger Causality Test results indicated that the direction of influence between the variables is liquidity $\rightarrow$ profitability, since the probability $(0.0023)$ is lower than the alpha risk (type I error) of 5\% (0.05). The opposite direction of influence is not confirmed by Granger Causality Test, as probability 0.3728 is greater than the alpha risk 0.05 . Thus, there is a long-term relationship between liquidity and profitability for the selected Bulgarian companies and the direction of impact between the variables is from liquidity to profitability.

\subsection{Empirical test of the Hypothesis 3}

The observations of percentage changes in quick liquidity ratio and return on current assets (Figure 2) show predomination of contrary movements of variables for the period 2007-2008 but after the initial crisis shock (the harsh World GDP contraction in 2009) the liquidity dynamics remains relatively constant and poorly related to variations in profitability.

It can also be outlined that the volatility of liquidity is much lower compared to profitability which is caused by the broader range of factors that influence the financial results of the business. Similar conclusion was observed by Niresh (2012).

The main conclusion is that the increased pressure of supporting business through liquidity in time of crisis was successfully implemented, resulting in poor correlation to changes in profitability. This means that financial managers smoothly dealt with liquidity problems, without affecting the potential for capital growth, thus, leaving it dependent on other factors and variables. 
Management, Vol. 22, 2017, 1, pp. 135-156

E. Raykov: The liquidity-profitability trade-off in Bulgaria in terms of the changed financial...

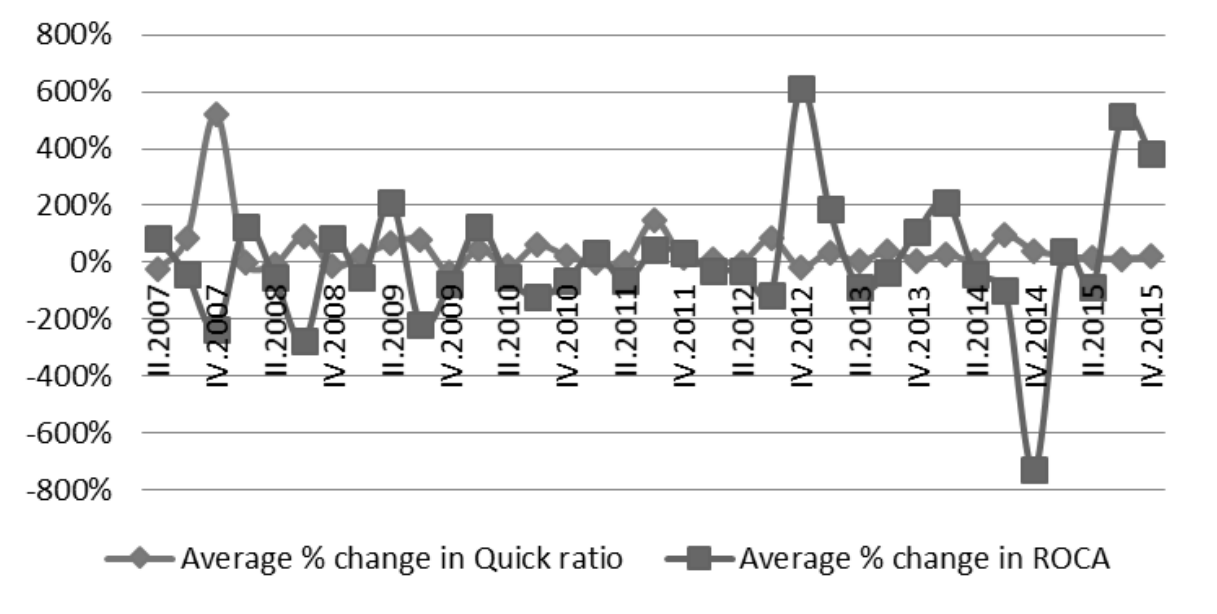

Figure 2. Statistics of average percentage change in selected indicators for selected Bulgarian companies (2007-2015)

Source: Bulgarian Stock Exchange, financial statements of selected companies, research results.

\section{CONCLUSIONS}

The analysis showed that the financial and economic crisis after 2007 developed a new role of the financial management as a leading concept responsible for a vast range of controlling, data provision and liquidity management matters resolved through balance of cash flows and current liabilities structure and value. This process resulted from the hard access to capital and scanty economic growth that required companies to find inner decisions for their outer problems. The main goal of financial management is undoubtedly maximization of owner's wealth through preserving profitability from submersion by raising the importance of liquidity in the overall management. Empirical tests showed that after 2007 financial managers in Bulgaria successfully isolated profitability from liquidity problems as the negative correlation between them is insignificant. Data analysis also reveals long-term influence of liquidity on profitability indicators, but not vice versa.

\subsection{Future research implications}

The overview of the liquidity profitability trade-off in terms of the changed financial management in crisis demonstrates the complexity of the discussed relation in terms of the causality, degree, time frame and even direction of impact. These results lead us to think that a more macroeconomic approach for 
Management, Vol. 20, 2017, 1, pp. 135-156

E. Raykov: The liquidity-profitability trade-off in Bulgaria in terms of the changed financial...

each situation might offer a better insight into the observed processes. Such analysis might consider economic and financial conditions in terms of the level of competition both for the consumers and the financial markets in each country or union. Similar direction of studying is recommended by Wasiuzzaman (2015) and Husaria (2015).

\section{REFERENCES}

1. Afza, T., Nazir, M. (2007). Working Capital Management Policies of Firms: Empirical Evidence from Pakistan, Conference Proceedings of 9th South Asian Management Forum (SAMF), North South University, Dhaka, Bangladesh

2. Ahmad, R. (2016). A Study of Relationship between Liquidity and Profitability of Standard Chartered Bank Pakistan: Analysis of Financial Statement Approach, Global Journal of Management and Business Research: C Finance, 16 (1), pp. 76-82.

3. Alikhan, R., Ali, M. (2016). Impact of Liquidity on Profitability of Commercial Banks in Pakistan: An Analysis on Banking Sector in Pakistan, Global Journal of Management and Business Research: C Finance, 16 (1), pp. 52-60

4. Argandona, A. (2012). Three Ethical Dimensions of Financial Crisis, Working Paper, WP-944, IESE Business School, University of Navarra, p. 5

5. Azkunaga, J., San-Jose,L., Urionabarrenetxea, S. (2013). The Impact of Financial Globalization and Financialization on the Economy in the Current Crisis through Banking Corporate Governance, p.79

6. Bardia S. (2004). Liquidity Management: A Case Study of Steel Authority of India Ltd, The Management Accountant (ICWAI, Kolkata) pp. 463 467

7. Batra, R., Kalia, A. (2016). Rethinking and Redefining the Determinants of Corporate Profitability, IMI Journal: Global Business Review, 17 (4), pp. 921-933

8. Bătrâncea, I., Bechi, L., Bătrâncea, L., Stoia (2013). Ratios Method - a Way of Measuring the Local Government Performance, Faculty of Economic Sciences - University of Oradea, p. 298.

9. Ben-Caleb, E., Olubukunola, U., Uwuigbe, U. (2014). Liquidity Management and Profitability of Manufacturing Companies in Nigeria, Journal of Business and Management, 5 (5), pp.81-90

10. Bulgarian National Bank (2016) [available at: http://bnb.bg/Statistics/ index.htm?toLang=_EN], [November 2016] 
11. CIMA (2011). Finance and organizational performance, shaping the future, Global Report Survey, p. 5

12. Bolek, M. (2014). Return on Current Assets, Working Capital and Required Rate of Return on Equity, Financial Internet Quarterly "EFinance”, 10 (2), pp. 1-10.

13. Bunget, C., Bureana, E. (2015). Testing the Violation of Conservatism Accounting Principle. Case Study on Romanian Listed Entities, Timisoara Journal of Economics and Business, 8 (2), pp. 183-202

14. Burja, K. (2011). Patrimonial Resources Management and The Economic Performance of Companies, Annales Universitatis Apulensis Series Oeconomica, 13 (1), p.15.

15. Cook, A. (2012). Internal Liquidity, Capital Structure and Firm Profitability: A Case for the South African Listed Real Estate Industry, Thesis (M.M. (Finance \& Investment)) - University of the Witwatersrand, Faculty of Commerce, Law and Management, Graduate School of Business Administration, pp. 1-67

16. Croal, J. (2003). Ratio Analysis, DIT 1006: Introduction to Management Information Systems, Villanova University, p. 4.

17. Deloof, M. (2003). Does Working Capital Management Affect Profitability of Belgian Firms? Journal of Business Finance and Accounting, 30 (3/4), pp. 573-587

18. Demirhan, H., Anwar, W. (2014). Factors affecting the Financial Performance of the Firms during the Financial Crisis: Evidence from Turkey, Ege Strategic Research Journal, 5 (1), pp. 65-80

19. Dimitrescu, D., Rasca, L., Firica, O. (2008). Financial Management in Crisis Situation - Pilot Study Regarding Romanian Practice, p. 2

20. Ehiedu, V. (2014). The Impact of Liquidity on Profitability of Some Selected Companies: The Financial Statement Analysis (FSA) Approach, Research Journal of Finance and Accounting, 5 (5), pp. 81-90

21. Eljelly, A. (2004). Liquidity - Profitability Tradeoff: an Empirical Investigation in an Emerging market, International Journal of Commerce and Management, 14 (2), pp. 48-61

22. Engle, R., Granger, C. (1987). Co-Integration and Error Correction: Representation, Estimation, and Testing, Econometrica, 55 (2), pp. 251276.

23. Ernst \& Young (2008). The Changing Role of the Financial Controller, Research report, p. 3

24. Ernst \& Young (2011). Views. Vision. Insights. The evolving role of today's $C F O$, Research report, p. 1

25. Gayathri, J. (2015). Review on working capital management, International Journal of Innovative Research and Development, 4 (9), pp. 261-272. 
Management, Vol. 20, 2017, 1, pp. 135-156

E. Raykov: The liquidity-profitability trade-off in Bulgaria in terms of the changed financial...

26. Giles, D. (2011). Testing for Granger Causality, Econometrics Beat: Dave Giles Blog

27. Husaria, A. (2015). The Effect of Working Capital Management on Firm's Profitability: Comparative Study on Middle East and West Europe Companies, Dissertação apresentada a Universidade Lusófona do Porto, pp. $1-110$

28. Irawan, A., Faturohman, T. (2015). A Study of Liquidity and Profitability Relationship: Evidence from Indonesian Capital Market, Proceedings of 31st The IIER International Conference, Bangkok, Thailand, p. 67

29. Khan, M., Jain, P. P. (2008). Financial Management - Text, Problems and Cases, Fifth Edition, McGraw - Hill Publishing Company Limited.

30. Khidmat, W., Rehman, M. (2014). Impact of Liquidity and Solvency on Profitability Chemical Sector of Pakistan, EMI Journal, 6 (3), pp. 3-13

31. Kung'u, J. (2017). Effect of Liquidity Management Practices on Profitability of Manufacturing Industry in Kenya, IOSR Journal of Economics and Finance, 8 (1), pp. 84-89

32. Lamberg, S., Valming, S. (2009). Impact of Liquidity Management on Profitability: A study of the Adaptation of Liquidity Strategies in a Financial Crisis, Thesis, UMEA School of Business, pp. 1-82

33. Levin, R., Travis, V. (1987). Small Company Finance: What the Books Don’t Say, Harvard Business Review, 65 (6), pp. 30-32

34. Maqsood, T., Anwar, M. (2016). Impact of Liquidity Management on Profitability in the Banking Sector of Pakistan, International Review of Management and Business Research, 5 (2), pp. 643-652

35. Mihajlov, K. (2014). Profitability during the Financial Crisis: Evidence from the Regulated Capital Market in Serbia, South-Eastern Europe Journal of Economics, 1, pp.7-33

36. Mushtaq. H., Chishti, A., Kanwal, S., Saeed, S. (2015). Tradeoff between Liquidity and Profitability, International Journal of Scientific Research and Management, 3 (5), pp. 2823-2842

37. Niranjan, M., Dutta, M., Burdwan, G. (2010) Impact of Working Capital Management on Liquidity, Profitability and Non-insurable Risk and Uncertainty Bearing: A Case Study of Oil and Natural Gas Commission (ONGC), Great Lakes Herald, 4 (2), pp. 23-41

38. Niresh, J. (2012). Trade-off between Liquidity and Profitability: a Study of Selected Manufacturing firms in Sri Lanka, Journal of Arts, Science and Commerce, III (4/2), pp. 34-40

39. Okay, G., Kose, A. (2015). Financial Performance Analysis of Brokerage Firms Quoted on the Istanbul Stock Exchange Using the TOPSIS Method of Analysis, International Journal of Business and Social Science, 6 (8/1), pp. 68-77 
40. Owolabi, A., Obida, S. (2012). Liquidity Management and Corporate Profitability: Case Study of Selected Manufacturing Companies Listed on the Nigerian Stock Exchange, Business Management Dynamics Journal, 2 (2), pp. 10-25

41. Pereira, L. C. (2010). The 2008 Financial Crisis and Neoclassical Economics, Brazilian Journal of Political Economy, 30 (1), pp. 3-26

42. Priya, K., Nimalathasan, B. (2013). Liquidity Management and Profitability: A Case Study of Listed Manufacturing Companies in Sri Lanka, International Journal of Technological Exploration and Learning, 2 (4), pp. 161-165

43. Ramagopal, C. (2008). Financial management - Aim and functions of finance, New Age International

44. Raykov, E. (2017). Integrated Approach to Working Capital Management in Terms of the Financial and Economy Crisis, Publishing Complex UNWE, pp. 1-234

45. Rudin, M., Djayani, N., Vita, F. (2016). The Effect of Liquidity and Leverage on Profitability of Property and Real Estate Company in Indonesian Stock Exchange, International Journal of Social Sciences and Management, 3 (4), pp. 300-304

46. Sahlman, W. (2009). Management and the financial crisis (Working paper), Harvard Business School, pp. 3-4

47. Saluja, P. P., Kumar, P. P. (2012). Liquidity and Profitability Trade-off, International Journal of Advanced Research in Management and Social Sciences, 1 (3), pp. 77-84

48. Samiloglu, F., Dermirgunes, K. (2008). The Effect of Working Capital Management on Firms' profitability: Evidence from Turkey, The International Journal of Applied Economics and Finance, 2 (1), pp. 44-50

49. Shin, H., Soenen, L. (1998). Efficiency of Working Capital Management and Corporate Profitability, Financial Practice and Education, 8 (1), pp. $37-45$

50. Siegel, J., Shim, J. (2000). Accounting Handbook, Third Edition, Barrons Edition, p. 241.

51. Szoka, K. (2015). Financial and payback net for SME's, Procedia Economics and Finance, 30, pp. 808-815

52. Tamragundi, A., Purushottam, V. (2016). Liquidity - Profitability Relationship : A Study of Ten Leading FMCG Companies in India, International Journal of Management, 7 (7), pp. 738-756

53. Untwal, N. (2011). Working Capital Management of Indian Tools LTD with Special Reference to Tool Industry, Indian Journal of Commerce and Management Studies, 2 (4), pp. 70-76 
Management, Vol. 20, 2017, 1, pp. 135-156

E. Raykov: The liquidity-profitability trade-off in Bulgaria in terms of the changed financial...

54. Valrshney, S. (2001). Trade Credit And Company Liquidity. The Management Accountant, 36 (10), pp. 738-756

55. Vieira, R. (2010). An Exploratory Study of Airline Companies Between 2005 - 2008, Master Thesis, UMEA University, pp. 1-39

56. Ware, E. (2015). Liquidity Management and its Effect on Profitability in Tough Economy: A Case of Companies Listed on the Ghana Stock Exchange, International Journal of Research in Business Studies and Management, 2 (11), pp. 34-66

57. Wasiuzzaman, S. (2015) Working capital and profitability in manufacturing firms in Malaysia: an Empirical Study, Global Business Review, 16 (4), pp. 545-556.

58. World Bank (2016) [http://data.worldbank.org/], [November 2016]

59. Wilson, G. (2004). Liquidity - Profitability Trade Off: An Empirical Investigation in Emerging Markets, Journal of Financial and Strategic Decision, 21 (5), pp. 7-11.

\title{
KOMPROMIS IZMEĐU LIKVIDNOSTI I PROFITABILNOSTI U BUGARSKOJ I PROMJENE FUNKCIJE FINANCIJSKOG MENADŽMENTA TIJEKOM KRIZE
}

\begin{abstract}
Sažetak
U ovom se radu analiziraju temeljne funkcije modernih financijskih menadžera i važni aspekti, povezani s njihovom ulogom u poslovnom okruženju. U svezi s globalnim promjenama, koje su zahvatile ekonomske i financijske sustave nakon 2007., uloga financijskih menadžera u korporacijama se uvelike mijenja. Navedeno se događa zbog povećanja broja funkcija koje financijski menadžeri obavljaju te povećanja njihova utjecaja na gotove sve aspekte aktivnosti poduzeća - od trgovine, logistike, preko upravljanja imovinom, do proizvodnje i tehnologije, a zbog promjena financijskih politika, promjena u opsegu djelatnosti i vremena donošenja odluka. Analiza u ovom radu ukazuje na povećanje uloge upravljanja gotovinom u vremenu krize i njen utjecaj na maksimiziranje poslovnih rezultata. Učinkoviti financijski menadžment bi trebao garantirati minimalan utjecaj na odluka o likvidnosti na profitabilnost $\mathrm{i}$ imovinu. Empirijski testovi za bugarsko gospodarstvo u doba krize pokazuju slabu vezu između kontrolirane likvidnosti i dugoročne operativne profitabilnosti, za koju se iskazuje jasan negativni predznak. Nadalje, promjenjivost likvidnost ostaje relativno niska i slabo je povezana sa značajnim varijacijama profitabilnosti. Nasuprot tome, kapitalni dobici ne djeluju značajno na likvidnost, zbog nestabilne profitabilnosti u analiziranom razdoblju.
\end{abstract}

Ključne riječi: funkcije financijskog menadžmenta, financijska i ekonomska kriza, nova uloga financijskih menadžera, kompromis između likvidnosti i profitabilnosti 
